\title{
Haemolymph parameters of Pacific white shrimp (Litopenaeus vannamei) infected with Taura syndrome virus
}

\author{
Yen-Ling Song ${ }^{1 *}$, Chun-I Yu ${ }^{1}$, Tzu-Wen Lien ${ }^{1}$, Chim-Cheng Huang ${ }^{1}$ and \\ Min-NAN Lin ${ }^{2}$ \\ ${ }^{1}$ Institute of Zoology, National Taiwan University, Taipei, Taiwan, 106, \\ Republic of China and ${ }^{2}$ Tainan Branch Station, Fisheries Research Institute, \\ Tainan, Taiwan, 72401, Republic of China
}

(Received 9 January 2001, accepted 21 May 2002)

\begin{abstract}
Pacific white shrimp (Litopenaeus vannamei) were injected with Taura syndrome virus (TSV) to assess shrimp immune responses and survival. TSV-infected shrimp suffered high mortality, but mock-infected and untreated shrimp experienced no mortality. Moribund shrimp were a pale, reddish colour and were lethargic and soft-shelled. Their haemolymph was clear red and coagulated poorly. In TSV-infected shrimp, the total haemocyte count (THC), hyalinocyte and granulocyte counts, and total plasma protein decreased significantly to $21 \%, 24 \%, 17 \%$ and $56 \%$ of untreated control values, respectively. Haemocyanin decreased to $67 \%$, and clottable proteins to $80 \%$ of control values $(P<0 \cdot 01)$. Copper and calcium ions, haemocytic transglutaminase (TGase) activity and plasma growth inhibitory activity against Vibrio harveyi also decreased significantly. Generation of intrahaemocytic superoxide anion, $\mathrm{O}_{2}^{-}$, in TSV-infected shrimp was significantly greater $(P<0.05)$ than in both control groups, no matter whether glucan stimulated or unstimulated. But the relative increase of intrahaemocytic $\mathrm{O}_{2}^{-}$generation in TSV-infected shrimp response to glucan stimulation was lower in both controls.

Plasma phenoloxidase (PO) activity increased significantly in TSV-infected shrimp. The plasma bacterial agglutinin titre against $E$. coli and $V$. harveyi, growth inhibition of $E$. coli and the concentration of magnesium ions in TSV-infected shrimp did not change significantly.

In conclusion, ten of thirteen haemolymph parameters changed significantly during the host-TSV interaction. These parameters might be valuable references of shrimp health status. (C) 2003 Elsevier Science Ltd. All rights reserved.
\end{abstract}

Key words: haemolymph; immunological parameters; Litopenaeus vannamei; Taura syndrome virus; biomarkers.

\section{Introduction}

The shrimp culture industry faces a crisis of diseases all over the world. More than 20 viral species have been identified from diseased shrimp [1]. Recent

*Corresponding author: song@ccms.ntu.edu.tw 
evidence shows that some diseases of cultured shrimp result from co-infection by different viruses [2]. A high percentage of wild-caught and healthy looking Penaeus monodon broodstock are White spot syndrome virus (WSSV) carriers [3]. Noninvasive screening of expensive brooders for WSSV, Taura syndrome virus (TSV), Yellow head disease virus (YHDV) and Infectious hypodermal and haematopoietic necrosis virus (IHHNV) is feasible. However, noninvasive screening for Monodon baculovirus (MBV) is not possible, because the hepatopancreas is the target organ. In addition, in a conventional culture system it is very difficult to keep a shrimp free of specific pathogens. Characterising the immune responses of healthy shrimp has been the focus of much research. Although a high prevalence of certain diseases is indicative of environmental degradation or poor management, disease symptoms are only crude indicators of stress. It is crucial to detect deleterious effects before stress results in disease that harms the population. Therefore, there is an urgent need for reliable, accurate and effective indicators of the physiological status of shrimp populations.

In vertebrates, certain diseases and toxins cause changes in blood characteristics. There is increasing evidence that the same is true in crustaceans [4]. Haemolymph is the most accessible internal tissue in shrimp. Taking haemolymph samples from shrimp does not increase mortality and has only short-term effects, if any, on haemolymph parameters, although this depends on the size of the shrimp and the amount of haemolymph collected [5]. However, little is known about which immunological parameters can be used as indicators in shrimp.

Taura syndrome virus (TSV) causes tremendous losses in cultured Pacific white shrimp (Litopenaeus vannamei) in the Americas [6-8]. Epizootics in white shrimp have also been observed in Taiwan since the accidental introduction of TSV in 1998 [9, 10]. In this study, Pacific white shrimp were artificially infected with a crude TSV extract. Haemolymph parameters were examined to determine (1) haematological changes in shrimp infected with TSV and (2) parameters that could be used as indicators to accurately assess shrimp physiological status.

\section{Materials and Methods}

\section{EXPERIMENTAL ANIMALS}

Apparently healthy, Pacific white shrimp, weighing 10 to $20 \mathrm{~g}$ each, were purchased from a local hatchery. Randomly sampled shrimp were confirmed to be TSV-free with an in situ hybridisation method using a specific DNA probe (DiagXotics, CT, U.S.A.) against TSV [10]. Shrimp with a negative signal in the cuticular epithelium of their pleopods were selected for the infection experiments. Selected shrimp were kept in a plastic tank $\left(75 \times 45 \times 45 \mathrm{~cm}^{3}\right)$ supplied with $100 \mathrm{l}$ of constantly flowing recirculating brackish water $(2 \%$ salinity, $25^{\circ} \mathrm{C}, 80-90 \mathrm{ppb}$ ammonia-N, 10-30 ppb nitrite). Shrimp were stocked at a density of 20-25 individuals per square metre. Shrimp were fed synthetic feed pellets, equivalent to $5 \%$ of their body weight, twice a day. Shrimp were 
conditioned for more than 1 month before infection. After infection or drawing of haemolymph, shrimp were returned to their tank and cultured until the end of the experiment.

\section{CRUDE TSV EXTRACT}

Shrimp collected during the naturally occurring Taura syndrome epizootics were stored at $-70^{\circ} \mathrm{C}$. Ten specimens from each batch were evaluated by in situ hybridisation using TSV-specific digoxigenin-labelled cDNA genomic probes (DiagXotics, Inc., CT, U.S.A.). Parallel shrimp were collected for viral extraction as the representative specimens showing a positive gene probe signal. Viral extraction was conducted as described by Lotz (1997) [11]. From each batch, samples of gills, appendages and tissues adjacent to the exoskeleton were homogenised and then centrifuged (Hitach, RPR20-4 rotor) at $17345 \times g$ for $5 \mathrm{~min}$ at $4^{\circ} \mathrm{C}$. Supernatants were harvested and filtered through a $0.45 \mu \mathrm{M}$ membrane (Millipore), then diluted 10 -fold with TN buffer (10 mM Tris-HCl, $400 \mathrm{~mm} \mathrm{NaCl}, \mathrm{pH} 7 \cdot 4)$ and used, fresh, for TSV-infection. For the mock-infection treatment, healthy looking, TSV-free shrimp were collected and processed as described above.

\section{ARTIFICIAL INFECTION}

Forty shrimp in each treatment, with two replicates each, were challenged. Each shrimp (at inter-molt stage) in the TSV treatment was injected intramuscularly, in the second abdominal segment, with $0 \cdot 1 \mathrm{ml}$ crude TSV extract. Mock-infected shrimp were injected with $0 \cdot 1 \mathrm{ml}$ extract prepared from healthy samples. These and the untreated shrimp served as controls. Clinical signs of disease and mortality of challenged shrimp were recorded daily.

\section{HAEMOLYMPH ANALYSIS}

On days two and three post-infection (dpi), 20 shrimp were randomly selected from each treatment. About $0.8 \mathrm{ml}$ of haemolymph were withdrawn from the ventral sinus in the first abdominal segment using a 26-gauge hypodermic needle on a $1-\mathrm{ml}$ syringe. Each syringe was pre-filled with $0.2 \mathrm{ml}$ of anticoagulant (10 mM Tris- $\mathrm{HCl}, 250 \mathrm{~mm}$ sucrose, $100 \mathrm{~mm}$ sodium citrate, $\mathrm{pH} 7 \cdot 6$ ). More anticoagulant was added to make an equal volume ratio of haemolymph to anticoagulant. Twenty haemolymph samples from each treatment were analysed individually. A volume of $50 \mu \mathrm{l}$ anticoagulated haemolymph was fixed with an equal volume of neutral buffered formalin (10\%) for $30 \mathrm{~min}$ to measure the total haemocyte count (THC) and differential haemocyte count (DHC). The remaining anticoagulated haemolymph was centrifuged at $300 \times \mathrm{g}$ for $10 \mathrm{~min}$ at $4^{\circ} \mathrm{C}$ to separate the haemocytes from plasma. Haemocytes were suspended and adjusted to $5 \times 10^{6}$ cells ml $^{-1}$ in ice-cold cacodylate buffer ( $0 \cdot 01 \mathrm{~m}$ sodium cacodylate, $0.45 \mathrm{M} \mathrm{NaCl}, 10 \mathrm{~mm} \mathrm{CaCl}_{2}, 26 \mathrm{~mm}$ $\mathrm{MgCl}_{2}, \mathrm{pH} 7 \cdot 0$ ). A volume of $600 \mu \mathrm{l}$ haemocyte suspension was separated for 
superoxide anion $\left(\mathrm{O}_{2}^{-}\right)$assays. The remaining haemocytes and plasma were immediately frozen in liquid nitrogen and thawed once for other assays.

TOTAL HAEMOCYTE COUNT (THC) AND DIFFERENTIAL HAEMOCYTE COUNT (DHC)

Fixed haemolymph was diluted 2, 4, 8, 16, and 32 times with ice-cold phosphate buffer saline (PBS, $20 \mathrm{~mm}, \mathrm{pH} 7 \cdot 2$ ). Total haemocytes were counted using a haemocytometer (Boeco, Germany) and light microscope at $100 \times$. Fixed haemolymph was smeared on a slide and stained with Giemsa solution $(10 \%)$ for $10 \mathrm{~min}$. The differential haemocytes were then characterised according to Tsing et al. (1989) [12], and 250-300 cells from each smear were counted under a light microscope at $1000 \times$.

GENERATION OF INTRAHAEMOCYTIC $\mathrm{O}_{2}^{-}$

Intrahaemocytic $\mathrm{O}_{2}^{-}$was measured as described by Song and Hsieh (1994) [13]. Briefly, $100 \mu \mathrm{l}$ of haemocyte suspension $\left(5 \times 10^{6}\right.$ cells ml $\left.^{-1}\right)$ was added to each of the three wells and then cytocentrifuged (Kubota, KN-70) at $300 \times g$ for $10 \mathrm{~min}$. After removing the supernatant, $100 \mu \mathrm{l}$ of $\beta$-1,3-1,6-glucan (4 mg $\mathrm{ml}^{-1}$ ) (Biotec Mackzymal, Tromso) was added and allowed to react for $30 \mathrm{~min}$ at $28^{\circ} \mathrm{C}$. For the unstimulated treatment, modified Complete Hank's Balanced Salt Solution (MCHBSS: 0.76 g CaCl$, 0.36 \mathrm{~g} \mathrm{MgSO}_{4}, 0.3 \mathrm{~g} \mathrm{MgCl}_{2}, 0.36 \mathrm{~g}$ $\mathrm{NaHCO}_{3}, 0 \cdot 32 \mathrm{~g} \mathrm{NaCl}, 24 \mathrm{~g}$ Complete HBSS (Gibco BRL) in $1 \mathrm{lddH} 2 \mathrm{O}$, with the osmolarity adjusted to $720 \pm 20 \mathrm{mOsm}$ ) was added to the remaining haemocyte suspension. Next, the immunostimulant solution was discarded, and haemocytes were washed and stained with $100 \mu \mathrm{l}$ redox dye, nitroblue tetrazolium (NBT; $0.3 \%$ ) for $30 \mathrm{~min}$ at $28^{\circ} \mathrm{C}$. The staining reaction was terminated by removing the NBT solution and adding absolute methanol. Haemocytes were washed with $70 \%$ methanol, air-dried, and flooded with a solution of $\mathrm{KOH}$ $(120 \mu \mathrm{l}, 2 \mathrm{M})$ and DMSO $(140 \mu \mathrm{l})$ to dissolve the cytoplasmic formazan. The optical density at $630 \mathrm{~nm}\left(\mathrm{OD}_{630}\right)$ of the dissolved cytoplasmic formazan was measured with a Precision microplate reader (Emax). The ratio (i.e. $\mathrm{OD}_{630}$ from glucan-stimulated haemocytes to $\mathrm{OD}_{630}$ of unstimulated haemocytes) was used as an index of the effect of TSV infection on haemocyte defensive activity.

PHENOLOXIDASE (PO) ACTIVITY

PO activity was assayed as described by Sung et al. (1994) [14] using L-3, 4-dihydroxyphenyl-alanine (L-dopa) (Sigma) as a substrate. To obtain lysates, frozen haemocytes were thawed and frozen several times. Haemocyte lysate supernatants (HLS) and plasma were assayed for PO activity using a spectrophotometer (Hitachi U-2000) to measure the $\mathrm{OD}_{490 \mathrm{~nm}}$. The concentration of total plasma protein was determined by the Bradford method (1976) [15] using bovine serum albumin (Bio-Rad Protein assay Kit II) as a standard. One unit of PO activity was defined as an increase in absorbance of $0.001 \mathrm{~min}^{-1} \mathrm{mg}$ protein $^{-1}[16]$.

TRANSGLUTAMINASE (TGASE) ACTIVITY

HLS TGase activity was assayed as described by Seiving et al. (1991) [17]. Casein $(200 \mu \mathrm{g} / \mathrm{well})$ bound to microtitre plates and biotin-labelled casein 
$(2: 1 \mathrm{w} / \mathrm{w})$ were used as substrates in a TGase-dependent cross-linking reaction. Each HLS was serially diluted two-fold with Tris-HCl (50 mm) and supplemented with $\mathrm{CaCl}_{2}$ to obtain a final concentration of $2 \cdot 2 \mathrm{~mm}$ in each well. Immobilised biotin was visualised by addition of streptavidin-labelled alkaline phosphatase (Calbiochem) followed by addition of $p$-nitrophenyl phosphate. Colour development was measured at $405 \mathrm{~nm}$. The standard curve of OD $405 \mathrm{~nm}$ against enzyme activity (unit $\mathrm{mg}^{-1}$ ) was established using guinea pig liver TGase (Sigma) as a standard. The protein concentration in HLS samples was determined by the Bradford method (1976) [15], using bovine serum albumin (Bio-Rad Protein assay Kit II) as a standard.

\section{CONCENTRATIONS OF CLOTTABLE PROTEIN AND HAEMOCYANIN IN PLASMA}

Rocket immunoelectrophoresis (RIEP) was used as described by Axelsen et al. (1975) [18]. The supporting matrix consisted of $0 \cdot 8 \%$ agarose (electroendosmosis- $\mathrm{Mr}<0 \cdot 1$, Amresco, Ohio, U.S.A.) in $37 \cdot 5 \mathrm{~mm}$ barbital buffer, $\mathrm{pH} 8 \cdot 6$. Rabbit antiserum against the purified clottable proteins [19] of tiger shrimp, $P$. monodon, was incorporated into the melted agarose to achieve a final concentration of $1 \%$. The mixture was solidified over a GelBond film (FMC Inc., Rockland, ME, U.S.A.). Wells (3 $\mathrm{mm}$ in diameter) were cut in the cathode side. Ten-fold diluted plasma samples (3 $\mathrm{ml}$ each) and purified tiger shrimp clottable proteins $\left(0 \cdot 2,0 \cdot 4,0 \cdot 6,0 \cdot 8\right.$ and $\left.1 \mathrm{mg} \mathrm{ml}^{-1}\right)$, which served as standards, were placed in each well. They were electrophoresed toward the anode side at $6 \mathrm{vcm}^{-1}$ at $4^{\circ} \mathrm{C}$. The electrophoresis reservoir contained $75 \mathrm{~mm}$ barbital buffer. Electrophoresis was run until the precipitate that formed between the antigen and antibody was rocket-shaped. Then the agarose gel film was washed in $0.3 \%$ and $0.5 \% \mathrm{NaCl}$ solutions, dried, and stained with Coomassie brilliant blue R-250. A standard curve and regression equation were generated using rocket height versus purified clottable protein concentration. The concentration of clottable proteins in plasma samples was calculated using the linear regression equation. Plasma haemocyanin also was quantified using RIEP. Rabbit antiserum (3\%) against tiger shrimp haemocyanin was incorporated into melted agarose. Two hundred-fold diluted plasma samples and purified tiger shrimp haemocyanin $(0.2,0.5,1.0,1.5$ and $2 \mathrm{mg} \mathrm{ml}^{-1}$ ) were then electrophoresed.

\section{PLASMA MAGNESIUM, CALCIUM AND COPPER}

Plasma cations were quantified with a flame atomic absorption spectrophotometer (Perkin-Elmer 3300AA) as described by Sung et al. (1991) [20]. A volume of $200 \mu \mathrm{l}$ plasma was added to $2 \mathrm{ml}$ nitric acid (65\%) and reacted for $2 \mathrm{~h}$ for complete digestion. The mixture was then diluted to a final volume of $10 \mathrm{ml}$ with deionised water and centrifuged at $1.500 \times g$ for $10 \mathrm{~min}$. The supernatant was harvested and its $\mathrm{OD}_{285 \mathrm{~nm}}$ for $\mathrm{Mg}, \mathrm{OD}_{423 \mathrm{~nm}}$ for $\mathrm{Ca}$, and $\mathrm{OD}_{324 \mathrm{~nm}}$ for $\mathrm{Cu}$ were measured spectrophotometrically. Stock solutions of pure magnesium, calcium and copper ions (Sigma) were diluted appropriately to create standards. Plasma cation levels were calculated using the linear regression equations obtained from the standard solutions. 
BACTERIAL AGGLUTINATION BY SHRIMP PLASMA

Bacterial agglutinin titre in shrimp plasma was measured using a microdilution plate test [21]. Escherichia coli D31 [22] and the shrimp pathogen Vibrio harveyi W36G were the targets. Bacteria were cultured in tryptic soy broth (Difco) for 18 to $24 \mathrm{~h}$ and then harvested. They were washed, re-suspended in PBS and inactivated by heating at $56^{\circ} \mathrm{C}$ for $1 \mathrm{~h}$. The bacterial suspension was adjusted to contain approximately $10^{9}$ cells $\mathrm{ml}^{-1}$ (i.e. the $\mathrm{OD}_{590 \mathrm{~nm}}$ was about $0 \cdot 85$ ). A $25 \mu \mathrm{l}$ plasma sample underwent a two-fold serial dilution in a round-bottom, 96-well microdilution plate (Nunc, Denmark). A pooled, plasma sample with strong agglutinating activity and PBS were run simultaneously as positive and negative controls. An equal volume of bacterial suspension was added to each well and the contents were mixed for $30 \mathrm{~s}$ by rotating the plate on a flat shaker. Plates were incubated overnight at $4^{\circ} \mathrm{C}$, and evaluated by eye or with a low power microscope. Bacterial agglutinin titres were recorded as the highest dilution in which visible agglutination occurred.

\section{INHIBITION OF BACTERIAL GROWTH BY SHRIMP PLASMA}

Inhibition was measured as described by Noga et al. (1994) [23], using a turbidometric assay with $E$. coli D31 and V. harveyi W36G as the bacterial targets. Briefly, $2 \mu \mathrm{l}$ of each shrimp plasma sample were added to $38 \mu \mathrm{l}$ PBS (pH 7·2). Then, $10 \mu \mathrm{l}$ of pre-cooled bacterial suspension $\left(10^{6}\right.$ cells $\left.\mathrm{ml}^{-1}\right)$ were added and the tubes were incubated for $30 \mathrm{~min}$ at $25^{\circ} \mathrm{C}$. The positive and negative plasma controls were tubes in which buffer, or a strongly inhibitory HLS sample [24, 25] was substituted for the test plasma. The reaction was stopped by placing all tubes in a $4^{\circ} \mathrm{C}$ water-bath and adding $450 \mu \mathrm{l}$ (at $4^{\circ} \mathrm{C}$ ) trypticase soy broth to each tube. Aliquots $(100 \mu \mathrm{l})$ of each sample mixture were partitioned into 4 wells of a 96-well, tissue-culture plate. When the optical density of the negative plasma control cultures (with bacteria but no plasma) reached an $\mathrm{OD}_{590 \mathrm{~nm}}$ of 0.090 to $0 \cdot 110$, the optical density of each well was recorded using an ELISA reader (Emax, Molecular Device). The inhibition of bacterial growth by plasma was defined as the bacterial growth $(\%)$ in the test plasma relative to the negative control.

STATISTICAL ANALYSIS

Analysis of variance followed by Student's $t$-tests at $0 \cdot 1 \%, 1 \%$ or $5 \%$ confidence levels were used to analyze comparative data. All data were expressed as a mean \pm standard deviation (s.D.).

\section{Results}

TSV-infected shrimp suffered greater than $80 \%$ cumulative mortality within 3 to 5 days of disease onset, but no mortality was observed in mock-infected or untreated shrimp (Fig. 1). None of the shrimp molted during the experiment. Moribund shrimp were anorexic and lethargic, exhibited ataxic swimming 


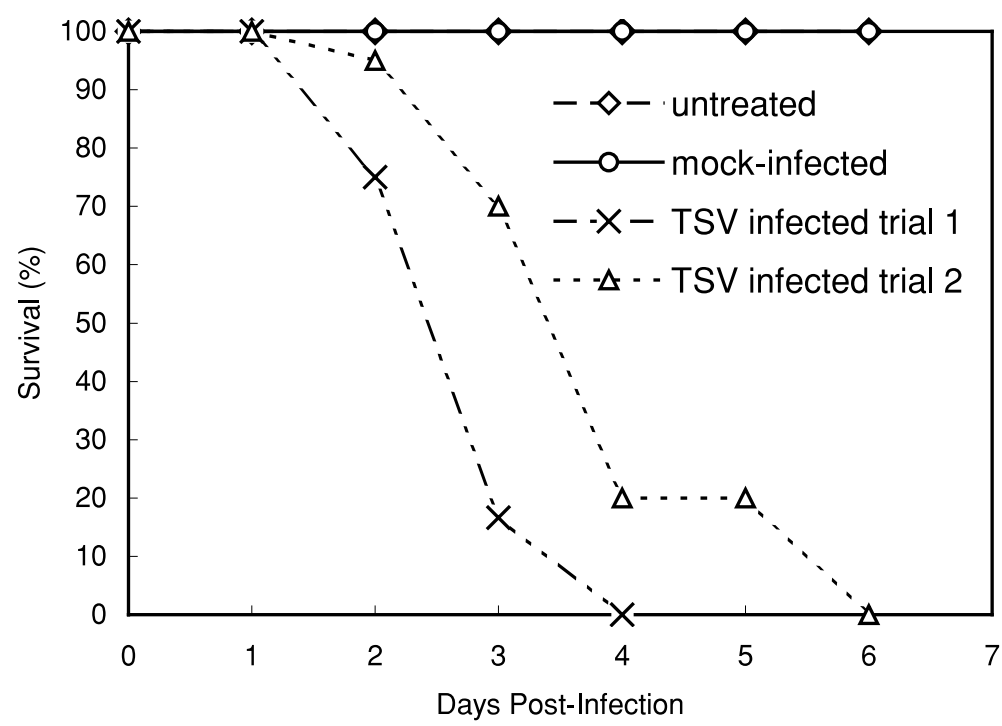

Fig. 1. Survival of white shrimp Litopenaeus vannamei artificially infected with Taura syndrome virus (TSV). There was no mortality of mock-infected and untreated shrimp.

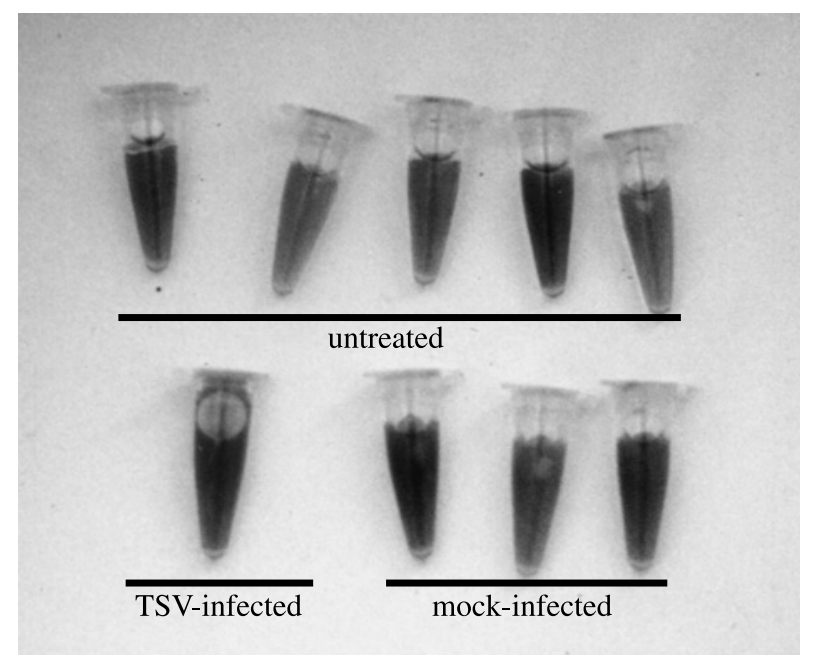

Fig. 2. Haemolymph from TSV-infected shrimp (lower left) was red while haemolymph from mock-infected and untreated shrimp was different shades of blue. An overlay of sterile liquid paraffin prevented atmospheric oxygen from diffusing into the haemolymph samples (Kodak ASA 400 film, exposure 1/2000 s).

behaviour, and had opaque musculature, a soft shell and pale reddish coloration that made the telson and pleopods distinctly red. These clinical signs were identical to those found in shrimp naturally infected with TSV. Haemolymph withdrawn from infected shrimp was red while that of mock-infected and untreated shrimp were different shades of blue (Fig. 2). In addition, the haemolymph of infected shrimp coagulated poorly. 
HAEMOCYTE ANALYSIS

The THC of TSV-infected shrimp was decreased by $79 \%$ relative to untreated shrimp. The THC of mock-infected shrimp increased 35\% relative to untreated shrimp, but this increase was not significant (Table 1, row 1). The hyalinocyte and granulocyte counts in TSV-infected shrimp decreased significantly to $24 \%$ and $17 \%$ of the counts in untreated controls, respectively (Table 1, row 2).

Generation of intrahaemocytic superoxide anion, $\mathrm{O}_{2}^{-}$, in TSV-infected shrimp was significantly greater $(P<0.05)$ than in both control groups, no matter whether glucan stimulated or unstimulated (Table 1, row 3). Unexpectedly, the relative increase in intrahaemocytic $\mathrm{O}_{2}^{-}$production in response to glucan stimulation was lower in TSV-infected shrimp than in both controls (data not shown).

Compared to both controls, TGase activity in haemocyte lysates decreased significantly in TSV-infected shrimp $(P<0 \cdot 05)$. However, no significant difference in TGase activity was detected between untreated and mock-infected shrimp (Table 1, row 4).

\section{PLASMA ANALYSIS}

Plasma PO activity in TSV-infected shrimp was $7 \cdot 5$-fold higher than in untreated shrimp $(P<0 \cdot 05)$. Mock-infection increased PO activity $2 \cdot 1$-fold (Table 1, row 5).

Plasma from TSV-infected shrimp significantly suppressed $V$. harveyi growth by $53 \%(P<0 \cdot 01)$. The same plasma slightly suppressed $E$. coli growth, but no significant difference in suppression was detected between plasma from TSV-infected and control groups (Table 1, row 6).

Against both $V$. harveyi and $E$. coli, the plasma agglutinin titre for shrimp in all three treatments ranged from $1: 2^{5}$ to $2^{7}$. There was no significant difference among treatments (Table 1, row 7).

In TSV-infected shrimp, total plasma protein decreased to $56 \%$ of the level in untreated shrimp $(P<0.01)$ (Table 1 , row 8). However, the major components, haemocyanin and clottable proteins, decreased to $67 \%$ and $80 \%$, respectively (Table 1 , rows 9 and 10). Haemocyanin, measured in terms of copper ion concentration, decreased to $68 \%(P<0 \cdot 01)$ (Table 1 , row 10$)$.

Calcium in the plasma of TSV-infected shrimp dropped to 16 to $20 \%$ of the levels in control shrimp $(P<0 \cdot 01)$ (Table 1 , row 11). The concentration of magnesium did not differ between TSV-infected and untreated shrimp, but it decreased to $96 \mathrm{mg} \mathrm{ml}^{-1}$ in mock-infected shrimp $(P<0 \cdot 01)$ (Table 1, row 11).

\section{Discussion}

Pacific white shrimp (L. vannamei) were injected with Taura syndrome virus (TSV) to assess shrimp immune responses and survival. In TSV-infected shrimp, the disease progressed faster in one replicate. The challenge conditions should have been identical, but it is possible the shrimp in one replicate received a higher dose of infectious viral particles. We did not quantify crustacean viruses because shrimp or susceptible crustacean cell lines are not 


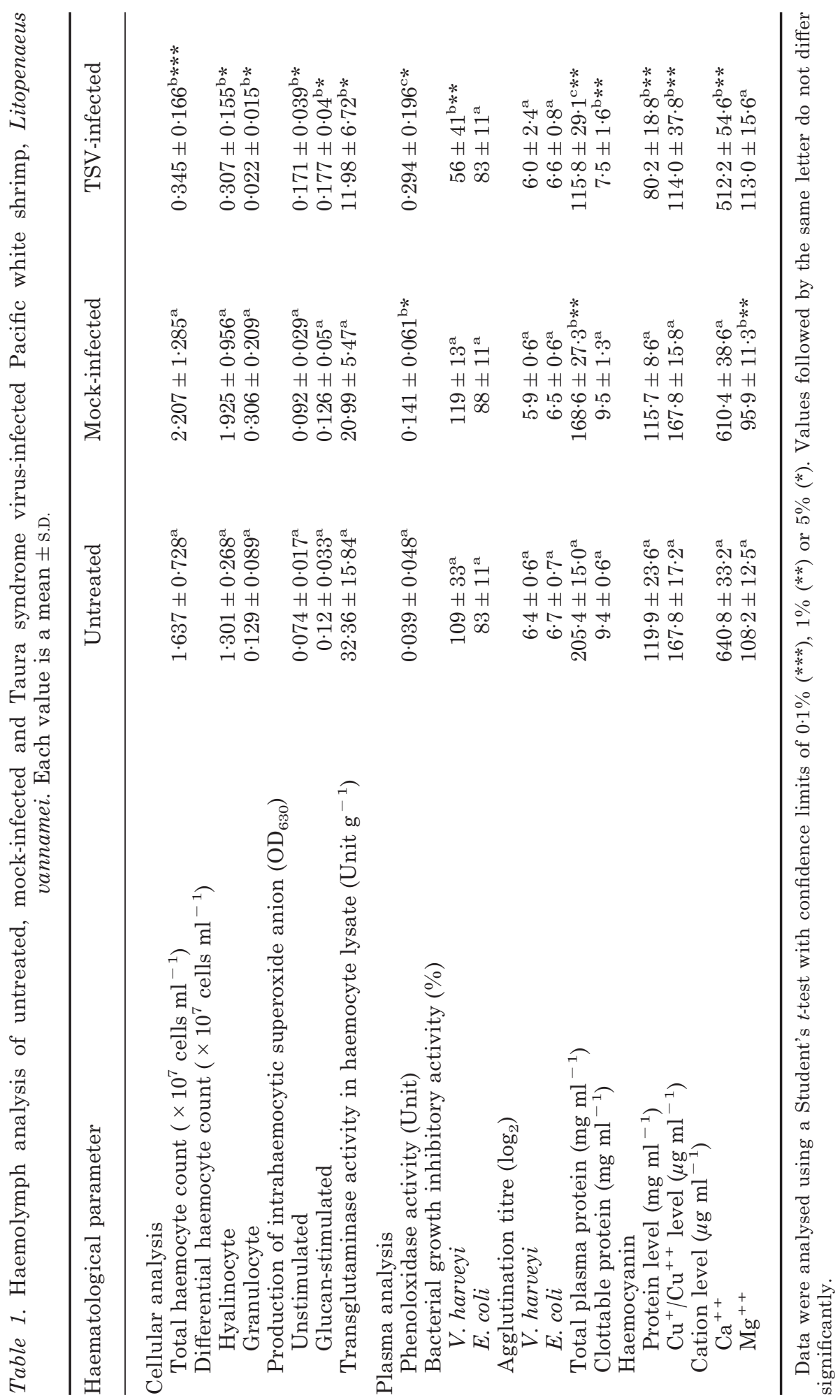


available. Both artificial challenges caused acute viral infection and $30 \%$ mortality of experimental shrimp at the midpoint of the challenge. Thus, the haemolymph data collected from one TSV-replicate on day 2 post-infection (dpi) and from the other TSV-replicate 3 dpi were pooled.

An array of biomarkers that could be used to evaluate shrimp health were measured. They included respiratory capacity (haemocyanin), nutritional state (total plasma protein), electrolytes (calcium and magnesium) and immunological parameters (haemocyte counts, agglutinin, bacterial growth inhibitory activity, clotting response, phagocytosis-related reactive oxygen intermediates and phenoloxidase activity). Although shrimp were fed with artificial pellets containing $\beta$-carotenoids, haemolymph taken from untreated and mockinfected shrimp was various shades of blue. The haemolymph of TSV-infected shrimp was reddish. The haemolymph of American lobsters infected with gaffkemia was pink. Haemolymph that is not blue is associated with abnormally low haemocyanin [4]. In this study, assays of both protein and copper levels indicated that plasma haemocyanin was significantly lower in TSV-infected shrimp. A decrease in haemocyanin was reported in blue crab infected with Paramoeba [26]. Because haemocyanin is a copper-containing pigment identified as the oxygen transport protein [27] in the extracellular fluid, 'anaemia' in shrimp can be diagnosed by a low concentration of haemocyanin in the haemolymph. Haemocyanin level should be recognised as a health biomarker in shrimp because it has many other pivotal functions including being an energy reservoir, osmoregulator and buffer. Total plasma protein decreased to $56 \%$ of control levels in TSV-infected shrimp, but the predominant components, haemocyanin and clottable proteins, only decreased to $67 \%$ and $80 \%$, respectively. Thus, other unknown plasma proteins may also be degraded during acute infection. Different assays applied to measure these variables may attribute, too.

TGase activity in haemocyte lysates, and plasma concentrations of clottable protein and calcium ions decreased in TSV-infected shrimp and coincided with poor haemolymph coagulation. Because TSV hampered coagulation, haemolymph loss via unhealed wounds would affect homeostasis. The non-trapped virus in the clot could invade, disseminate and eventually cause systemic viremia. In TSV-infected shrimp, haemolymph colour and clotting changed, but clarity did not. Thus, haemolymph colour and clotting may also be valuable health biomarkers.

The THC of untreated white shrimp was $1.64 \pm 0.73 \times 10^{7} \mathrm{ml}^{-1}$. In kuruma shrimp (P. japonicus) the THC was $1.7 \times 10^{7}$ [28] and in blue shrimp (P. stylirostris) $1.84 \pm 0.96 \times 10^{7}$ [29]. In tiger shrimp $(P$. monodon) the THC ranged from $2 \cdot 10 \times 10^{7}$ (flow cytometry) to $2 \cdot 33 \times 10^{7}$ (haemocytometer) [30]. In a different study, tiger shrimp THC values ranged from $2 \cdot 67 \pm 0 \cdot 44 \times 10^{7}$ (ATP analysis) to $2 \cdot 72 \pm 0 \cdot 31 \times 10^{7}$ (haemocytometer) [31]. THC varies among and within species. Haemocyte abundance is affected by type of circulatory system (open or closed), sex, molting, development, reproductive status and nutrition $[32,30]$. The THC of TSV-infected white shrimp decreased 79\%. The THC of $P$. monodon and P. japonicus infected with WSSV also decreased significantly [28, 31]. Haemocyte lysis [33], cell recruitment towards infected tissues, nodule formation [34] or interference with haematopoiesis could contribute to lower 
THC. In addition, hypoxia significantly decreased the THC in P. stylirostris and stressed shrimp became susceptible to Vibrio alginolyticus infection [29]. In contrast, THC increased in peptidoglycan-fed kuruma shrimp, resulting in enhanced resistance against WSSV infection [28]. Thus, changes in THC, though not virus-specific, could be useful indices of changes in shrimp health.

The DHC, like THC, decreased significantly during acute infection. However, the percentage values of DHC, when arc sine transformed, did not change during infection (data not shown). This indicates that TSV-infection affected all types of haemocytes equally, including hyalinocytes and granulocytes. In shrimp, the proPO system and penaeidins originate from circulating granulocytes [25, 35]. TGase has been found in the hyalinocytes of decapod crustaceans [36] and the granulocytes of crayfish [37]. The location of TGase in white shrimp has not been determined. Although all types of haemocytes are involved, to various degrees, in immune responses, the DHC may not be a useful bioindicator.

Indirect evidence suggests that white shrimp can recognise TSV with specific, unidentified recognition molecules (probably capsid proteins), stimulating activation of the proPO-system. Microbial cell wall components, such as $\beta$-glucan from fungi, lipopolysaccharide (LPS) from Gram negative bacteria and peptidoglycan (PG) from Gram positive bacteria can activate the invertebrate proPO system. It can also be activated by viral components. In normal shrimp, haemocytes aggregate rapidly and occur at wound sites and around infected cells. Therefore, it is plausible that the haemocytes containing proPO might release it and a thiol-ester-like motif [38]. Like vertebrate complement molecules, proPO is cleaved and activated. This PO enzyme binds to infected cells via a probable thiol-ester-like motif, leading to production of toxic intermediates of phenol, which might aid in preventing the virus from gaining entry into the body cavity. In crayfish, $a_{2}$-macroglobulin (a proteinase inhibitor) can be cross-linked to the clotting protein by a blood cell TGase. This inhibitor is thought to locate within the clotting polymers to prevent microorganisms from using their proteinases to dissolve clots and penetrate wound sites [39]. Whether this is the case in shrimp needs further investigation. However, haemolymph leakage resulting from impaired coagulation appears to be compensated by enhanced PO activity in TSV-infected shrimp. As in crayfish [40], shrimp proPO may be activated directly by a $20 \%$ reduction in plasma calcium, which indicates an injury caused by TSV infection.

In the present study, plasma PO activity was low because it was expressed as $\triangle$ OD mg plasma protein ${ }^{-1} \mathrm{~min}^{-1}$. Direct measurements of pure PO are needed to obtain accurate estimates. Based on generation of the initial product, $\mathrm{O}_{2}^{-}$, haemocyte phagocytosis increased $1 \cdot 3$-fold. However, TSV infection seemed to exhaust the haemocytes. As a result, haemocyte phagocytosis decreased dramatically, as indicated by the lowest ratio value. In TSV-infected shrimp, one of the plasma antibiotics known to suppress $V$. harveyi growth increased. Tiger shrimp naturally and artificially infected with $V$. damsela had melanised granulomatous ulcerations of the hepatopancreas and an activated proPO-system [41]. The immune responses of shrimp are similar to those of other crustaceans. The pro-PO-activating system is an important part of their immune response, which includes recognition of foreign invaders and 
nonliving entities, activation of a wide range of defence reactions, such as phagocytosis and antibacterial activity, encapsulation and nodule formation.

Although there was agglutination activity against $E$. coli and $V$. harveyi in the plasma of untreated shrimp, agglutinin titre did not change after TSVinfection. Sritunyalucksana et al. (1999) [42] obtained similar results after immunostimulating $P$. monodon. Agglutination in the haemocyte lysate fraction did not increase even when the treatment was supplemented with divalent calcium ions. In shrimp, lectins defend against bacteria via self/ non-self recognition [43-46]. A variety of lectins, not only divalent, cationdependent or -independent lectins [47], are present in plasma. Some lectins, such as penaeidins, are synthesised constitutively [25], but monodin synthesis occurred following induced bacterial infection [45].

In this study, the plasma of healthy L. vannamei inhibited growth of E. coli, but not $V$. harveyi. TSV infection induced inhibition of $V$. harveyi growth, but not affecting activity against $E$. coli. It seems that a variety of antibiotics are present in plasma. Some can be synthesised constitutively, whilst others synthesised after induction. Previous papers reported that the haemolymph from unstimulated $P$. monodon and $P$. setiferus strongly inhibited growth of E. coli, V. fluvialis and V. parahaemolyticus [48, 42]. In P. monodon, stimulation with peptidoglycan did not affect the haemolymph's inhibition of $V$. parahaemolyticus growth [42]. Further research is needed to understand these disparate results.

Because of their pivotal importance to crustacean health, electrolytes, particularly magnesium, are attractive biomarkers [4]. Elevated magnesium levels were associated with white spot disease in kuruma shrimp [28]. However, in this study, magnesium levels in TSV-infected white shrimp did not change. Therefore, additional research is needed to fully assess the usefulness of electrolytes as biomarkers.

Shrimp are notorious for possessing background interference to the immune response assays used here. Injection of carry-over shrimp proteins (in the mock-infected group) did not stimulate the immune response, except to increase PO activity and decrease total plasma protein and magnesium levels. Thus, the untreated controls were adequate to assess the effects of the injection and carrier solution. The proPO-system of insects and crustaceans is so sensitive it can be activated by less than $10 \mathrm{pg}$ of microbial polysaccharides [49]. In addition, injection always has short-term effects on the haemal parameters of crustaceans [5]. The magnitude of these effects depends on the amount of blood loss. Thus, shrimp always maintain a low level of alertness to pathogens and/or environmental change.

The present results indicate that agglutinin, magnesium level and, probably, growth inhibitory activity are not reliable bioindicators of shrimp health status. That 10 of 13 haemolymph parameters changed dramatically during shrimp-TSV interaction suggest no single parameter should be expected to adequately assess shrimp health. Thus, to obtain the most accurate assessment of shrimp health a panel of complementary parameters should be selected.

We thank Prof. Inn-Ho Tsai, Institute of Biochemical Science, NTU, for generously providing purified haemocyanin and clottable protein and the respective rabbit 
antisera. The authors also thank Prof. Saulwood Lin, Institute of Oceanography, NTU, for quantitating haemolymph cations with atomic-absorption spectrophotometry. This work was financially supported by grants (88-AST-1.4-FID-02 (4-5) and 89-ST-1.2-FA-04 (11)) from the Council of Agriculture, Republic of China.

\section{References}

1 Lightner, D. V. \& Redman, R. M. (1998). Strategies for the control of viral diseases of shrimp in the Americas. Fish Pathology 33, 165-180.

2 Wang, Y. C. \& Chang, P. S. (2000). Yellow head virus infection in the giant tiger prawn Penaeus monodon cultured in Taiwan. Fish Pathology 35, 1-10.

3 Lo, C. F., Ho, C. H., Chen, C. H., Liu, K. F., Chiu, Y. L., Yeh, P. Y., Peng, S. E., Hsu, H. C., Liu, H. C., Chang, C. F., Su, M. S., Wang, C. H. \& Kou, G. H. (1997). Detection and tissue tropism of white spot syndrome baculovirus (WSBV) in captured brooders of Penaeus monodon with a special emphasis on reproductive organs. Diseases of Aquatic Organisms 30, 53-72.

4 Noga, E. J. (2000). Hemolymph biomarkers of crustacean health. In Recent Advances in Marine Biotechnology, Immunobiology and Pathology, Vol. 5 (M. Fingerman \& R. Nagabhushanam, eds) pp. 125-163. Enfield, NH: USA: Science Publishers, Inc.

5 Lorenzon, S., Guarrini, S., Smith, V. J. \& Ferrero, E. A. (1999). Effects of LPS injection on circulating haemocytes in crustaceans in vivo. Fish and Shellfish Immunology 9, 31-50.

6 Lightner, D. V. (1995). Taura syndrome: an economically important viral disease impacting the shrimp farming industries of the Americas including the United States. In Proceedings of the Ninety-ninth Annual Meeting USAH. Reno, Nevada, pp. 36-52. Richmond, VA: Pat Campbell \& Associates.

7 Brock, J. A., Gose, R., Lightner, D. V. \& Jasson, K. W. (1995). An overview on Taura syndrome, an important disease of farmed Penaeus vannamei. In Swimming Through Troubled Water, Proceedings of the Special Session on Shrimp Farming, Aquaculture '95 (C. L. Browdy \& J. S. Hopkins, eds) pp. 84-89. Baton Rouge, LA: World Aquaculture Society.

8 Hasson, K. W., Lightner, D. V., Mohney, L. L., Redman, R. M., Poulos, B. T. \& White, B. M. (1999). Taura syndrome virus (TSV) lesion development and the disease cycle in the Pacific white shrimp Penaeus vannamei. Diseases of Aquatic Organisms 36, 81-93.

9 Tu, C., Huang, H. T., Chuang, S. H., Hsu, J. P., Kuo, S. T., Li, N. J., Hsu, T. L., Li, M. C. \& Lin, S. Y. (1999). Taura syndrome in Pacific white shrimp Penaeus vannamei cultured in Taiwan. Diseases of Aquatic Organisms 38, 159-161.

10 Yu, C. I. \& Song, Y. L. (2000). Outbreaks of Taura syndrome in pacific white shrimp Penaeus vannamei cultured in Taiwan. Fish Pathology 35, 21-24.

11 Lotz, J. M. (1997). Effect of host size on virulence of Taura virus to the marine shrimp Penaeus vannamei (Crustacea: Penaeidae). Diseases of Aquatic Organisms $30,45-51$.

12 Tsing, A., Arcier, J. M. \& Brehelin, M. (1989). Hemocytes of penaeid and Palaemonid shrimps: morphology, cytochemistry and hemegram. Journal of Invertebrate Pathology 53, 64-77.

13 Song, Y. L. \& Hsieh, Y. T. (1994). Immunostimulation of tiger shrimp (Penaeus monodon) hemocytes for generation of microbicidal substances: analysis of reactive oxygen species. Developmental and Comparative Immunology 18, 201-209.

14 Sung, H. H., Kou, G. H. \& Song, Y. L. (1994). Vibriosis resistance induced by glucan treatment in tiger shrimp (Penaeus monodon). Fish Pathology 29, 11-17.

15 Bradford, M. M. (1976). A rapid and sensitive method for the quantitation of microgram quantities of proteins utilizing the principle of protein-dye binding. Analytical Biochemistry 72, 248-254.

16 Söderhäll, K. \& Unestam, T. (1979). Activation of serum prophenoloxidase in arthropod immunity: The specificity of cell wall glucan activation and activation by 
purified fungal glycoproteins of crayfish phenoloxidase. Canadian Journal of Microbiology 25, 406-414.

17 Seiving, B., Stenberg, P. \& Nilsson, B. (1991). A new assay for transglutaminase. Scandinavian Journal of Clinical \& Laboratory Investigation 51, 119-124.

18 Axelsen, N. H., Kroll, J. \& Weeke, B. (1975). A manual of quantitative immunoelectrophoresis. Universitetsforlaget, Oslo, $230 \mathrm{pp}$.

19 Yeh, M. S., Chen, Y. L. \& Tsai, I. H. (1998). The hemolymph clottable proteins of tiger shrimp, Penaeus monodon, and related species. Comparative Biochemistry and Physiology 121B, 169-176.

20 Sung, H. H., Song, Y. L. \& Kou, G. H. (1991). Potential uses of bacterin to prevent shrimp vibriosis. Fish and Shellfish Immunology 1, 311-312.

21 Roberson, B. S. (1990). Bacterial agglutination. In Techniques in Fish Immunology (J. S. Stolen, T. C. Fletcher, D. P. Anderson, B. S. Roberson \& W. B. van Muiswinkel, eds) pp. 81-86. Fair Haven, USA: SOS Publications.

22 Boman, H. G. \& Hultmark, D. (1987). Cell-free immunity in insects. Annual Review of Microbiology 41, 103-126.

23 Noga, E. J., Engel, D. P., Arroll, T. W., McKenna, S. \& Davidian, M. (1994). Low serum antibacterial activity coincides with increased prevalence of shell disease in blue crabs Callinectes sapidus. Diseases of Aquatic Organisms 19, 121-128.

24 Destoumieux, D., Bulet, P., Loew, D., Dorsselaer, A. V., Rodriguez, J. \& Bachère, E. (1997). Penaeidins, a new family of antimicrobial peptides isolated from the shrimp Penaeus vannamei (Decapoda). Journal of Biological Chemistry 272, 2839828406.

25 Destoumieux, D., Muñoz, M., Cosseau, C., Rodriguez, J., Bulet, P., Comps, M. \& Bachère, E. (2000). Penaeidins, antimicrobial peptides with chitin-binding activity, are produced and stored in shrimp granulocytes and released after microbial challenge. Journal of Cell Science 113, 461-469.

26 Pauley, G. B., Newman, M. W. \& Gould, E. (1975). Serum changes in the blue crab, Callinectes sapidus associated with Paramoeba perniciosa, the causative agent of gray crab disease. Marine Fishery Review 37, 34-38.

27 Cameron, J. N. \& Mangum, C. P. (1983). Environmental adaptations of the respiratory system: Ventilation, circulation and oxygen transport. In The Biology of Crustacea, ol. 8 (F. J. Vernberg \& W. B. Vernberg, eds) pp. 43-63. NY: Academic Press.

28 Hennig, O., Itami, T., Maeda, M., Kondo, M., Natsukari, Y. \& Takahashi, Y. (1998). Analyses of hemolymph immunoparameters in kuruma shrimp infected with penaeid rod-shaped DNA virus. Fish Pathology 33, 389-393.

29 Le Moullac, G., Soyez, C., Saulnier, D., Ansquer, D., Avarre, J. C. \& Levy, P. (1998). Effect of hypoxic stress on the immune response and the resistance to vibriosis of the shrimp Penaeus stylirostris. Fish \& Shellfish Immunology 8, 621-629.

30 Owens, L. \& O'Neill, A. (1997). Use of a clinical cell flow cytometer for differential counts of prawn Penaeus monodon haemocytes. Diseases of Aquatic Organisms 31, $147-153$.

31 Chang, C. F., Su, M. S. \& Chen, H. Y. (1999). A rapid method to quantify total haemocyte count of Penaeus monodon using ATP analysis. Fish Pathology 34, 211-212.

32 Le Moullac, G., Le Groumellec, M., Ansquer, D., Froissard, S., Levy, P. \& Aquacop. (1997). Haematological and phenoloxidase activity changes in the shrimp Penaeus stylirostris in relation with the moult cycle: protection against vibriosis. Fish \& Shellfish Immunology 7, 227-234.

33 Omori, S. A., Martin, G. G. \& Hose, J. E. (1989). Morphology of hemocyte lysis and clotting in the ridgeback prawn, Sicyonia ingentis. Cell Tissue Research 255, $117-123$.

34 Martin, G. G., Kay, J., Poole, D. \& Poole, C. (1998). In vitro nodule formation in the ridgeback prawn, Sycionia ingentis, and the American lobster, Homarus americanus. Invertebrate Biology 117, 155-168. 
35 Sung, H. H., Chang, H. J., Her, C. H., Chang, J. C. \& Song, Y. L. (1998). Phenoloxidase activity of hemocytes derived from Penaeus monodon and Macrobrachium rosenbergii. Journal of Invertebrate Pathology 71, 26-33.

36 Martin, G. G., Hose, J. E., Omori, S., Chong, C., Hoodbhoy, T. \& McKrell, N. (1991). Localization and roles of coagulogen and transglutaminase in hemolymph coagulation in decapod crustaceans. Comparative Biochemistry and Physiology 100B, 517-522.

37 Wang, R., Liang, Z., Hal, M. \& Söderhall, K. (2001). A transglutaminase involved in the coagulation system of the freshwater crayfish, Pacifastacus lenisusculus. Tissue localization and cDNA cloning. Fish \& Shellfish Immunology 11, 623-637.

38 Sritunyalucksana, K., Cerenius, L. \& Söderhäll, K. (1999). Molecular cloning and characterization of prophenoloxidase in the black tiger shrimp, Penaeus monodon. Developmental and Comparative Immunology 23, 179-186.

39 Hall, M. \& Söderhäll, K. (1994). Crayfish $a$-macroglobulin as a substrate for transglutaminases. Comparative Biochemistry and Physiology 108B, 65-72.

40 Söderhäll, K. \& Cerenius, L. (1992). Crustacean immunity. Annual Review of Fish Diseases 1, 3-23.

41 Song, Y. L., Cheng, W. \& Wang, C. H. (1993). Isolation and characterization of Vibrio damsela infectious for cultured shrimp in Taiwan. Journal of Invertebrate Pathology 61(1), 24-31.

42 Sritunyalucksana, K., Sithisarn, P., Withayachumnarnkul, B. \& Flegel, T. W. (1999). A preliminary study on activation of agglutinin and antibacterial activity in haemolymph of the black tiger prawn, Penaeus monodon. Fish \& Shellfish Immunology 9, 21-30.

43 Kondo, M., Matsuyama, H. \& Yano, T. (1992). The opsonic effect of lectin on phagocytosis by hemocytes of kuruma prawn, Penaeus japonicus. Gyobyo Kenkyu 27, 217-222.

44 Ratanapo, S. \& Chulavatnatol, M. (1990). Monodin, a new sialic acid-specific lectin from black tiger prawn (Penaeus monodon). Comparative Biochemistry and Physiology 97B, 515-520.

45 Ratanapo, S. \& Chulavatnatol, M. (1992). Monodin-induced agglutination of Vibrio vulnificus, a major infective bacterium in black tiger prawn (Penaeus monodon). Comparative Biochemistry and Physiology 102B, 855-859.

46 Vargas-Albores, F., Guzman, M. \& Ochoa, J. (1993). A lipopolysaccharide-binding agglutinin isolated from brown shrimp (Penaeus californiensis Holmes) haemolymph. Comparative Biochemistry and Physiology 104B, 407-413.

47 Kondo, M., Itami, T. \& Takahashi, Y. (1998). Preliminary characterization of lectins in the hemolymph of kuruma prawn. Fish Pathology 33, 429-435.

48 Noga, E. J., Arroll, T. A., Bullis, R. A. \& Khoo, L. (1996). Antibacterial activity in hemolymph of white shrimp, Penaeus setiferus. Journal of Marine Biotechnology 4, 181-184.

49 Söderhall, K. (1999). Editorial. Developmental and Comparative Immunology 23(4/5), 263-266. 